\title{
The Effect Of Ethanol Extract From Lingzhi Fungi (Ganoderma Lucidum) Cianjur Isolate On Syndecan-1 Expressions In Kb CCL17 Oral Cancer Cell
}

\section{Efek Ekstrak Ethanol Dari Jamur Lingzhi (Ganoderma Lucidum) Isolat Cianjur Terhadap Ekspresi Syndecan-1 Pada Sel Kanker Rongga Mulut Kb Ccl-17}

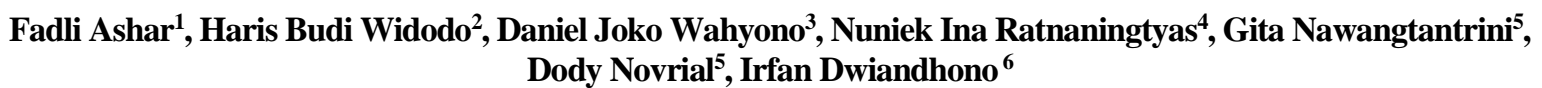

\author{
${ }^{1}$ Biomedical Sciences, Faculty of Medicine, \\ Universitas Jenderal Soedirman, Purwokerto, Indonesia \\ ${ }^{2}$ Oral Biology Department, Faculty of Medicine, \\ Universitas Jenderal Soedirman, Purwokerto, Indonesia \\ ${ }^{3}$ Department of Molecular Genetics, Faculty of Biology, \\ Universitas Jenderal Soedirman, Purwokerto, Indonesia \\ ${ }^{4}$ Department of Microbiology, Faculty of Biology, \\ Universitas Jenderal Soedirman, Purwokerto, Indonesia \\ ${ }^{5}$ Anatomy Pathology Department, Faculty of Medicine, \\ ${ }^{6}$ Dentistry, Faculty of Medicine \\ Universitas Jenderal Soedirman, Purwokerto, Indonesia \\ Universitas Jenderal Soedirman, Purwokerto, Indonesia \\ Jl. Dr. Soeparno, Kampus Karangwangkal Gedung E, \\ Karang Bawang, Grendeng, Kec. Purwokerto Utara, \\ Kabupaten Banyumas, Jawa Tengah 53122, Indonesia \\ Email: pustaka.fadliashar5@gmail.com
}

\begin{abstract}
Intercellular adhesion plays a role in cancer formation and protein has a key potential in maintaining cell adhesion, including syndecan-1. Meanwhile, oral cancer originates from the oral epithelium, which has an invasive and metastatic level. Its treatments involving chemotherapy and radiotherapy commonly leave unfavorable side effects, hence, suitable alternatives are needed. Natural ingredients are widely used as an alternative treatment for cancer, for example, Ganoderma lucidum (G. lucidum) which has anti-cancer and anti-angiogenic properties, induces apoptosis, stimulates an immune response, inhibits the degradation of Extracellular matrix (ECM), reduces inflammation, affects cell cycles, cytotoxic, and acts as an antioxidant.This study aims to determine the effect of ethanol extract from Ganoderma lucidum Cianjur isolate on syndecan-1 expression in KB CCL-17 oral cell cancer. This was an experimental study with a post-test only control group design, the treatment group used $G$. lucidum ethanol extract with a concentration of $2.12 \mu \mathrm{g} / \mathrm{ml}(\mathrm{P} 1), 4.24 \mu \mathrm{g} / \mathrm{ml}$ (P2), and $8.49 \mu \mathrm{g} / \mathrm{ml}(\mathrm{P} 3)$, while the positive control group used cisplatin with a concentration of $11.5 \mu \mathrm{g} / \mathrm{ml}(\mathrm{K} 1)$. In contrast, the negative control used aquadest (K0), while syndecan-1 expression was observed using the immunohistochemical examination. The highest syndecan-1 expansion rate was found in the treatment group with a concentration of $8.49 \mu \mathrm{g} / \mathrm{ml}$. A significant difference was indicated by one-way ANOVA ( $<<0.05)$ between K0 - K1, K0 - P1, K0 - P2, K0 - P3, K1 - P1, K1 - P2, K1 - P3, P1 - P2, as well as P1 and P3. The administration of ethanol extract from G. lucidum Cianjur isolate increases syndecan-1 expression in KB CCL-17 oral cell cancer.
\end{abstract}

Keywords: Syndecan-1, oral squamous cell carcinoma, Ganoderma lucidum, KB CCL-17

Abstrak

Adhesi sel antar sel memainkan peran terhadap pembentukan kanker. Protein yang berperan dalam mempertahankan adhesi sel adalah Syndecan-1. Kanker rongga mulut berasal dari epitel rongga mulut yang memiliki tingkat invasif dan metastasis. Perawatan kanker yang mengalami invasif dan metastasis dilakukan perawatan kemoterapi dan radioterapi, namun efek dari perawatan tersebut memiliki efek samping yang tidak menguntungkan, untuk itu dibutuhkan perawatan 
alternatif. Pengobatan menggunakan bahan alam mulai digunakan sebagai alternatif perawatan kanker. Salah satu bahan alam sebagai anti kanker adalah Ganoderma lucidum(G.lucidum) yang memiliki kemampuan anti angiogeneis, menginduksi apoptosis, menstimulasi respon imunitas, menghambat degradasi Ekstracelullar matrix (ECM), mengurangi inflamasi, mempengaruhi siklus sel, kemampuan sitotoksis dan sebagai antioksidan. Mengetahui ekspresi syndecan-1 yang diberikan ekstrak etanol Ganoderma lucidum isolat Cianjur pada kultur sel rongga mulut KB CCL-17.Desaign penelitian yang digunakan adalah post-test only with control group design. Kelompok perlakuan menggunakan ekstrak etanol G.lucidum dengan konsentrasi 2,12 $\mu \mathrm{g} / \mathrm{ml}$ (P1), 4,24 $\mu \mathrm{g} / \mathrm{ml}(\mathrm{P} 2)$ dan 8,49 $\mu \mathrm{g} / \mathrm{ml}$ (P3). Kelompok kontrol positif menggunakan Cisplatin dengan konsentrasi 11, $5 \mu \mathrm{g} / \mathrm{ml}(\mathrm{K} 1)$ dan Kelompok kontrol negatif menggunakan aquabidest (K0). Ekspresi syndecan-1 diamati dengan pemeriksaan imunohistokimia.Rerata ekspesi syndecan-1 tertinggi pada kelompok perlakuan dengan konsentrasi ekstrak etanol G.lucidum konsentrasi 8,49 $\mu \mathrm{g} / \mathrm{ml}$. Perbedaan signifikan ditunjukan menggunakan analisis one way ANOVA $(\mathrm{p}<0,05)$ antara K0 dengan K1, K0 dengan P1, K0 dengan P2, K0 dengan $\mathrm{P} 3$, K1 dengan $\mathrm{P} 2$, K1 dengan $\mathrm{P} 2, \mathrm{~K} 1$ dengan $\mathrm{P}$, $\mathrm{P} 1$ dengan $\mathrm{P} 2$ dan $\mathrm{P} 1$ dengan $\mathrm{P} 3$. Terdapat peningkatan jumlah pada ekspresi syndecan-1 yang diberikan ekstrak etanol G.lucidum isolat Cianjur pada kultur sel rongga mulut (KB CCL17)

Kata kunci: Syndecan-1, Immunohistokimiaoral squamosa cell carcinoma, Ganoderma lucidum, KB CCL-17

\section{INTRODUCTION}

Oral cancer had an incidence of 354,864 cases in 2018 , with a mortality rate of $177,384 .^{1}$ The increased incidence is influenced by poor prognosis, low survival rates, and poor radiotherapy treatment. ${ }^{2}$ Besides, cancer has an invasive and metastatic ability, which accounts for $90 \%$ of the deaths. Protein and gene expression are used to predict the invasiveness and metastasis, hence, they are used as a reference in determining tumor prognosis ${ }^{3}$.

Syndecan-1 is commonly applied as a diagnostic standard biomarker by analyzing the number of expressions which often decrease due to the down regulation mechanism of cancer ${ }^{4}$. Cancers with a decreased expression of syndecan-1 are commonly found in the lungs, kidneys, as well as head and neck. $^{5}$

Cancer treatment uses surgical therapy combined with radiotherapy and/or chemotherapy, but these treatments have side effects on the patients. ${ }^{5,7}$ Therefore, suitable and safe alternatives such as natural ingredients are needed to minimize the side effects. Ganoderma lucidum ( $G$. lucidum) is a fungus that is cytotoxic, has anti-cancer properties by inducing apoptosis, suppressing invasive cancer cells, regulating key signaling molecules, ${ }^{8}$ inhibiting progressive cell cycles, and suppressing angiogenesis. ${ }^{8} 9$.

Studies on the effect of G. lucidum Cianjur ethanol extract and Syndecan-1 expression on KB CCL-17 oral cancer cell has not been conducted. Therefore, this study aims to determine the potential of this natural ingredient in inhibiting the develop-ment of oral cancer.

\section{MATERIALS AND METHODS}

This study used a post-test group-only design with a purely experimental approach. The treatment group was given $G$. lucidum ethanol extract with a concentration of $2.12,4.24$, and $8.49 \mu \mathrm{g} / \mathrm{ml}$, while the positive control group was treated using cisplatin at a concentration of $11.5 \mu \mathrm{g} / \mathrm{ml}$ and the negative control was administered with aquadest. Each treat-ment and control was repeated four times, while the G. lucidum fungus used in the study was obtained from the CV Asa Agro Corporation. It was har-vested after four months of planting, and three months after the fruit body sprung out. The fungus lives in the lowlands with a temperature of $30^{\circ} \mathrm{C}$, humidity of approximately $80 \%$, and a $\mathrm{pH}$ of 7 . It was collected in September 2019 and the part used was 300 grams thinly sliced fruiting body, which were placed into an oven of $70^{\circ} \mathrm{C}$ for 2 hours for drying. The extract method used was maceration with $96 \%$ ethanol solvent. The ratio of solvent to powder was 5:5 with $1,500 \mathrm{ml}$ of ethanol containing 300 grams of powder. The mixture was stirred and tightly closed with aluminum foil, left for $3 \times 24$ hours by stirring, and filtered every day.

KB CCL-17 cancer cells obtained from ATCC with epithelial morphology were taken from liquid nitrogen tanks and then diluted with water baths at $37^{\circ} \mathrm{C}$. The cells were inserted into centrifuge tubes containing $10 \mathrm{~mL}$ DMEM-serum medium and centrifuged within 10 minutes at $1200 \mathrm{rpm}$. The supernatant was separated between sediment and liquid, while the precipitate formed along with DMEM, was kept for 20 minutes, then the centrifuge was performed at $1200 \mathrm{rpm}$ for 10 minutes. Further-more, 
the next suspension was placed into Tissue Culture Flask (TCF) with a growth medium containing $20 \%$ FBS and then viewed under an in-verted microscope. Living cells appeared round, glowing, and clear. The TCF was incubated in an incubator at $37^{\circ} \mathrm{C}$ and $5 \%$ $\mathrm{CO}_{2}$ with a non-tense lid, while the cells were given treatment when $80 \%$ con-fluent occurred, which was marked with a yello-wing medium. Moreover, the cells were treated with the extracts and incubated for 24 hours on a 24 well microplate. They were further washed with $500 \mu \mathrm{L}$ Phosphate buffer saline (PBS), $7 \%$ ethanol and $3 \%$ hydrogen peroxide at $100 \mu \mathrm{L}$, and kept for 10 minutes. The solution was then discarded with a micropipette, and the coverslip was washed with $500 \mu \mathrm{L}$ PBS. PBS was taken with a 1 $\mathrm{mL}$ micro-pipette and transferred to a glass preparation. Pre-diluted blocking serum of $100 \mu \mathrm{L}$ was dropped and kept for 10 minutes, then, an immunohistochemistry examination was performed to observe syndecan-1 expressions.

Subsequently, data were tabulated and tested for normality by Shapiro-Wilk, then, the analysis was performed using the one-way ANOVA test. When the data is normally distributed with a confidence level of 95\% ( $p<0.05$ ), a post-hoc Least Significance Difference (LSD) test was performed to determine the presence of significant differences between the groups.

\section{RESULTS}

Immunohistochemical observations were performed on 10 random Microscope fields of view with a magnification of 400 times. The results showed positive brown Syndecan-1 on cytoplasm and negative with no staining. The syndecan-1 ex-pression on immunohistochemical examination is shown in Figure 1.

The analysis results of Syndecan-1 expression in oral cancer KB CCL-17 culture are shown in Table 1 , shows the mean of syndecan- 1 expression in the KB CCL-17 oral cancer cell culture from each group. Syndecan-1 expression was mostly observed in the treatment group at a concentration of $8.49 \mu \mathrm{g} / \mathrm{ml}$, with a mean of $34.59 \%$. In contrast, the smallest expression was found in the non-treatment group with a mean of $1.51 \%$. Based on the results, the mean of syndecan-1 expression in the oral cancer cell culture with ethanol extract increased proportionally with the increasing concentration.

After the mean was obtained, statistic tests were performed, including normality test using ShapiroWilk and homogeneity using the Levene test, then the one-way ANOVA was used to analyze the data. The normality test showed a significance value of
0.125 , while Shapiro-Wilk results showed that the data were normally distributed with $p>0.05$. Furthermore, the homogeneity test obtained a significance value of 0.233 after the data were transformed. A value of $p>0.05$ indicates homogeneity, hence, the data were used.

The one-way ANOVA parametric statistical test requires that data have normal distribution and homogeneity. It was used to analyze differences in syndecan-1 expression between groups and treatments. Table 2 depicts the test results.

Based on the results, the expression of syndecan-1 in oral cancer cell KB-CCL-17 cultures between the non-treatment group, as well as others treated with cisplatin, and G.lucidum ethanol extract of 2.12 $\mu \mathrm{g} / \mathrm{ml}, 4.24 \mu \mathrm{g} / \mathrm{ml}$ and $8.49 \mu \mathrm{g} / \mathrm{ml}$ had significant differences with a value of $0.000(p<0.05)$. Furthermore, there was a significant difference in the oneway ANOVA parametric test, while the LSD test was conducted to identify significant differences between the groups. Table 3 depicts the LSD parametric test results.

The LSD parametric test results in Table 3 showed that there were differences in the expression of syndecan-1 between each group, except the P2 and P3 groups. The difference was categorized as significant when the $\mathrm{p}$-value is $<0.05$. The significance value of the $\mathrm{P} 2$ and $\mathrm{P} 3$ groups was 0.40 .

\section{DISCUSSION}

Based on the results, there were differences between the groups without treatment, as well as cisplatin, G. lucidum ethanol extract at $2.12 \mu \mathrm{g} / \mathrm{ml}$ (P1), $4.24 \mu \mathrm{g} / \mathrm{ml}(\mathrm{P} 2)$, and $8.49 \mu \mathrm{g} / \mathrm{ml}(\mathrm{P} 3)$. Further tests using LSD showed that there were significant differences in the expression of syndecan-1 between the non-treatment, cisplatin, and treatment groups of P1, P2, P3. Ethanol extract of G. lucidum increased the syndecan-1 expression in oral cancer cell $\mathrm{KB}$ CCL-17. Meanwhile, the expression is related to cell growth regulation, pro-liferation, the interaction between heparin and growth factor groups, angiogenesis induction, growth promotion, tumor progression, and contributes directly to invasive and metastatic abilities in malignant tumors ${ }^{10}$.

A correlation between metastases in invasive ductal carcinoma and the number of syndecan-1 expressions in primary tumors was found in previous studies. This occurred because syndecan-1 is expressed in more than $90 \%$ of epithelium tumors. The high expression is related to the maintenance of epithelial cell morphology and increasing the interaction of cell adhesion with matrix components. Aside from maintaining cell adhesion as a physio- 
logical function, syndecan-1 also regulates pathological processes, such as invasive tumor cells, angiogenesis, and metastasis ${ }^{10,11}$

Based on the above data, the lowest mean of syndecan-1 expression was found in the group without treatment. This is because the expression is reduced in epithelial tumors in relation to the prognosis as well as due to an increase in MMP-9 which has opposite effects with syndecan-1, hence, a decrease in MMP-9 expression increases the syndecan- 1 expression $^{13}$

Syndecan-1 expression in ameloblastoma shows that Desmoplastic Ameloblastoma has a smaller number compared to other types. ${ }^{14}$ Multicystic types which have invasive properties from weak to strong are follicular, akantomatos, granular, plexiform, and desmoplastic types, respectively. ${ }^{16}$ Furthermore, in odontogenic keratocyst, unicystic ameloblastoma, and dentigerous cyst, low syndecan-1 expression increases the invasive and destructive ability of neoplastic cells in unicystic ameloblastoma and extends to surrounding tissues. ${ }^{16}$ The mean of expression in epithelial tissues with ameloblastoma showed a decrease of $26.3 \%$, keratocystic odontogenic tumor (KCOT) $92.3 \%$, and dentigerous cyst $100 \%$. There was an association with cell differentiation and invasive ability into deeper tissues on malignancy. $\mathrm{Al}$ Otaibi, et al. found that the mean of syndecan-1 expression in normal cells was more than mild, moderate, and severe dysplasia in the oral cancer cell, but there was no significant difference between tumor grades. ${ }^{15,18}$

Syndecan-1 also increases in human fibrosarcoma cell line HT-1080. It stimulates malignancy by increasing proliferation, metastatic potential, and migration ability. Overexpression of the branch bypasses the ectodomain, but it has amino acids in the juxta-membrane that promote proliferation and chmotaxis. The ectodomain increases tumor cell proliferation by the migratory ability of syndecan-1, which is enhanced by syndecan-2. Increased syndecan-1 expression triggers IGF1R activation and elevates Ets-1 proliferation. Moreover, syndecan-2 transfection with an upregulated mechanism increases the chemotaxis migration of HT-1080 cells to the ECM protein. The proliferation of HT-1080 cells occurs due to hyper-phosphorylation of $\mathrm{Rb}$ (retinoblastoma) by the CDK2 (cyclin-dependent kinase 2) -cyclin E1 complex. This process is also stimulated by syndecan-1, hence, increasing its expression also raises syndecan-2. ${ }^{17,18}$

Increased expression of syndecan-1 reduces the ability of cell proliferation by prolonging $\mathrm{G} 1$ and $\mathrm{S}$ phases in the cell cycle and retarded migration. The results show that syndecan-1 work simultaneously in inhibiting the motility and cycle of mesenchymal cells that are not present in the ectodomain, hence, it has a dual role. ${ }^{17}$

There was no significant difference in the mean of syndecan-1 expression in the $\mathrm{P} 2$ and $\mathrm{P} 3$ treatment groups. In other words, G. lucidum ethanol extract of $4.24 \mu \mathrm{g} / \mathrm{ml}$ and $8.49 \mu \mathrm{g} / \mathrm{ml}$ had a comparable abi-lity to increase syndecan-1 expression. Based on the LSD parametric test, there was a significant difference in the expression between $\mathrm{P} 1$ and $\mathrm{P} 3$ groups, as well as between $\mathrm{P} 2$ and $\mathrm{P} 3$ groups. These results showed that the ethanol extract with a concentration of $4.24 \mu \mathrm{g} / \mathrm{ml}$ and $8.49 \mu \mathrm{g} / \mathrm{ml}$ was stronger against the increased syndecan-1 expression compared to $2.12 \mu \mathrm{g} / \mathrm{ml}$.

The treatment groups, as well as negative and positive controls, had syndecan-1 below the normal value which is greater than $66 \% .{ }^{19}$ Moreover, there was a significant difference in the syndecan- 1 expression in the $\mathrm{K} 1$ group (cisplatin) with $\mathrm{P} 2$ as well as the K1 Group with P3. These results indicate that the effectiveness of $G$. lucidum ethanol extract was higher than cisplatin as a chemotherapy agent.

Decreased expression of more than $80 \%$ of oral cancer is a risk factor for recurrence and death after 24 months of surgery, hence, syndecan-1 in the stroma is a reliable indicator of oral cancer prognosis. The increased expression associated with cytotoxic treatment shows clear predictive factors and a good prognosis in oral cancer. ${ }^{20}$ Furthermore, the loss of syndecan-1 in breast cancer causes reduced metastasis in the brain, therefore, when the expression increases, the potential risk of metastasis to the brain is elevated. Also, the loss of syndecan-1 triggers changes in breast cancer cells to secrete cytokines/chemokines that affect BBB (Blood-brain barrier). The cytokines / chemokines regulated by syndecan-1 are IL-8, IL-6, and IL-34. Altogether, they influence the integrity and transmigration of BBB mediated by CCL5, ICAM-1, IL-6, IL-8, and GM-CSF. The syndecan-1 expression on fibroblast stroma and endothelial cells enhances growth, angiogenesis, and forms a microenvironment that favors invasive breast cancer ${ }^{21}$. Syndecan-1 expression in fibroblast stroma is needed to perform metastasis in $4 \mathrm{~T} 1$ breast cancer mice. ${ }^{22}$

Nevertheless, the expression by some cancers is not always a risk factor for increasing metastasis to the brain. Prostate cancer characterized by an increased syndecan- 1 expression has a low incidence of metastasis to the brain namely $0.2-2 \%$. The syndecan-1 expression also increases in lung cancer, but the presence of a correlation with a good or poor prognosis is unclear. ${ }^{23}$

These results indicate that the ethanol extract of $G$. Lucidum effectively increases the number of syn- 
decan-1 expressions, therefore, G. Lucidum needs to be developed as a potential anti-cancer agent to suppress the invasive and metastatic levels of oral cancer. In conclusion, the administration of ethanol extract from G. lucidum Cianjur isolate increases syndecan-1 ex-pression in KB CCL-17 oral cancer cells.

\section{ACKNOWLEDGEMENTS}

The authors are grateful to the Dean of the Faculty of Medicine in Jenderal Soedirman University for the study fund assistance, the Institute for Research and Community Service (LPPM) of Jenderal Soe-dirman University for the grants through the Dosen Pemula Research Funds 2018 Batch II. They are also grateful to the Microbiology Laboratory in the Faculty of Biology, Integrated Training and Testing Laboratory (LPPT) Unit III of Gadjah Mada Uni-versity, and Anatomy Pathology Laboratory of Dr. Sardjito Hospital Yogyakarta for the facilities provided.

\section{TABLES}

Table1. Analysis Results of Syndecan-1 Expression in oral cancer cell KB CCL-17 Culture.

\begin{tabular}{lll}
\hline No & Group & Mean $(\%) \pm \mathrm{SD}$ \\
\hline 1 & Without Treatment & $1.51 \pm 0.52$ \\
2 & Cisplatin $11.5 \mu \mathrm{g} / \mathrm{ml}$ & $25.53 \pm 2.45$ \\
3 & $\begin{array}{l}\text { Ethanol Extract of G.lucidum - Concentration } \\
\text { of } 2.12 \mu \mathrm{g} / \mathrm{ml}\end{array}$ & $10.77 \pm 1.33$ \\
& & \\
4 & $\begin{array}{l}\text { Ethanol Extract of G.lucidum-Concentration } \\
\text { of } 4.24 \mu \mathrm{g} / \mathrm{ml}\end{array}$ & $32.29 \pm 6.05$ \\
& & \\
& $\begin{array}{l}\text { Ethanol Extract of G.lucidum - Concentration } \\
\text { of } 8.49 \mu \mathrm{g} / \mathrm{ml}\end{array}$ & $34.59 \pm 1.66$
\end{tabular}

Source: Primary data was processed, 2020

Table2. One-way ANOVA test on Syndecan-1 Expression

\begin{tabular}{llllll}
\hline & Sum of squares & df & Mean squares & $F$ & Sig. \\
\hline $\begin{array}{l}\text { Between } \\
\text { Groups }\end{array}$ & 2048.128 & 4 & 512.032 & 48.641 & .000 \\
& 94.741 & 9 & 10.527 & & \\
Within Groups & 9142.869 & 13 & & & \\
Total & 2140 & & & \\
\hline
\end{tabular}

Source: Primary data was processed, 2020 
Table3. Results of LSD Parametric Tests between Groups on Syndecan-1 Expressions

\begin{tabular}{|c|c|c|c|c|c|c|}
\hline No. & Group & K0 & K1 & $\mathrm{P} 1$ & $\mathrm{P} 2$ & P3 \\
\hline 1 & K0 & & $\begin{array}{l}24.031 * * \\
(p=0.000)\end{array}$ & $\begin{array}{c}-9.265^{*} \\
(\mathrm{p}=0.012)\end{array}$ & $\begin{array}{l}-30.875 * * \\
(p=0,000)\end{array}$ & $\begin{array}{l}-33.092 * * \\
(\mathrm{p}=0.000)\end{array}$ \\
\hline 2 & $\mathrm{~K} 1$ & $\begin{array}{l}24.031 * * \\
(p=0.000)\end{array}$ & & $\begin{array}{l}14.766^{* *} \\
(\mathrm{p}=0.000)\end{array}$ & $\begin{array}{c}-6.753^{*} \\
(p=0.031)\end{array}$ & $\begin{array}{c}-9.060^{*} \\
(0.008)\end{array}$ \\
\hline 3 & $\mathrm{P} 1$ & $\begin{array}{c}9.265^{*} \\
(\mathrm{p}=0.012)\end{array}$ & $\begin{array}{l}-14.766^{* *} \\
(p=0.000)\end{array}$ & & $\begin{array}{l}-21.520 * * \\
(\mathrm{p}=0.000)\end{array}$ & $\begin{array}{c}-23.826 * * \\
(0.000)\end{array}$ \\
\hline 4 & $\mathrm{P} 2$ & $\begin{array}{l}30.785 * * \\
(\mathrm{p}=0.000)\end{array}$ & $\begin{array}{c}6.753 * \\
(p=0.031)\end{array}$ & $\begin{array}{l}21.520 * * \\
(\mathrm{p}=0.000)\end{array}$ & & $\begin{array}{c}-2.306 \\
(\mathrm{p}=0.407)\end{array}$ \\
\hline 5 & P3 & $\begin{array}{l}33.092 * * \\
(\mathrm{p}=0.000)\end{array}$ & $\begin{array}{l}9.060^{*} \\
(0.008)\end{array}$ & $\begin{array}{c}23.826^{* * *} \\
(0.000)\end{array}$ & $\begin{array}{c}2.306 \\
(\mathrm{p}=0.407)\end{array}$ & \\
\hline Description: & $\begin{array}{l}* \\
* * \\
\mathrm{~K} 0 \\
\mathrm{~K} 1 \\
\mathrm{P} 1 \\
\mathrm{P} 2 \\
\mathrm{P} 3\end{array}$ & \multicolumn{5}{|c|}{$\begin{array}{l}=\text { signficant }(\mathrm{p}<0.05) \\
=\text { very significant }(\mathrm{p}<0.01) \\
=\text { negative control (without treatment) } \\
=\text { positive control }(\text { cisplatin } 11.35 \mu \mathrm{g} / \mathrm{ml}) \\
=\text { ethanol extract of } \text { G.lucidum } \text { with concentration of } 2.12 \mu \mathrm{g} / \mathrm{ml} \\
=\text { ethanol extract of } \text { G.lucidum } \text { with concentration of } 4.24 \mu \mathrm{g} / \mathrm{ml} \\
=\text { ethanol extract of } \text { G.lucidum } \text { with concentration of } 8.49 \mu \mathrm{g} / \mathrm{ml}\end{array}$} \\
\hline
\end{tabular}

Source: Primary data was processed, 2020

\section{FIGURES}

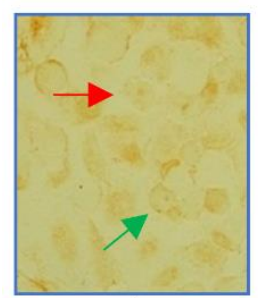

A

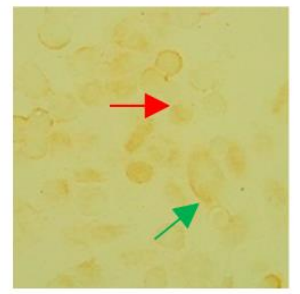

B

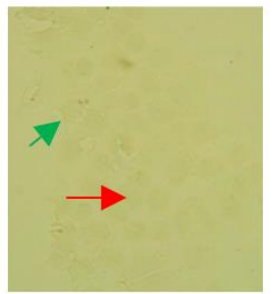

C

Figure 1. Expression of Syndecan-1 with A. treatment ethanol extract; B. Cisplatin; C. Aquades on immunohistochemical examination

$\rightarrow$ : cells that did not express syndecan-1

$\rightarrow$ : cells that expressed syndecan-1

Source: Primary data was processed, 2020

\section{REFERENCE}

1. Bray F, Ferlay J, Soerjomataram I, Siegel RL, Torre LA, Jemal A. Global cancer statistics 2018: GLOBOCAN estimates of incidence and mortality worldwide for 36 cancers in 185 countries. CA Cancer J Clin. 2018; 68(6): 394-424.

2. Noguti J, De Moura CFG, De Jesus GPP, Da Silva VHP, Hossaka TA, Oshima CTF, et al. Metastasis from oral cancer: an overview. Cancer GenomicsProteomics. 2012; 9(5): 329-35;
3. Arellano-Garcia ME, Li R, Liu X, Xie Y, Yan X, Loo $\mathrm{JA}$, et al. Identification of tetranectin as a potential biomarker for metastatic oral cancer. Int J Mol Sci. 2010; 11(9): 3106-21;

4. Muramatsu T. Reduced Expression of Syndecan-1 in Oral Cancer. Oral Cancer2012;

5. Liang Z, Yi Y, Guo Y, Wang R, Hu Q, Xiong X. Chemical characterization and antitumor activities of polysaccharide extracted from Ganoderma lucidum. Int J Mol Sci. 2014; 15(5): 9103-16. 
6. Szatmari T, Dobra K. The role of syndecan-1 in cellular signaling and its effects on heparan sulfate biosynthesis in mesenchymal tumors. Front Oncol. 2013; 3: 310

7. Szatmari T, Otvos R, Hjerpe A, Dobra K. Syndecan-1 in cancer: Implications for cell signaling, differentiation, and prognostication. Dis Markers. 2015; 2015: 796052

8. Huang SH, O'Sullivan B. Oral cancer: Current role of radiotherapy and chemotherapy. Med Oral Patol Oral Cir Bucal. 2013;18(2): 233-40.

9. Martinez-Montemayor MM, Acevedo RR, OteroFranqui E, Cubano LA, Dharmawardhane SF. Ganoderma lucidum (Reishi) inhibits cancer cell growth and expression of key molecules in inflammatory breast cancer. Nutr Cancer. 2011; 63(7): 1085-94

10. Mujahid I, Muchtashjar. Uji proliferasi dan uji apoptosis ganoderma lucidum (curtis) p.karst sebagai anti kanker serviks. Prosiding Seminar hasil penelitian LPPM UMP. 2014.

11. Carreon-Burciaga RG, Gonzalez-Gonzalez R, MolinaFrechero N, Lopez-Verdin S, Pereira-Prado V, Bologna-Molina R. Differences in e-cadherin and syndecan-1 expression in different types of ameloblastomas. Anal Cell Pathol (Amst). 2018; 2018: 9392632

12. Ningsih D. Aktivitas antidiabetes dari fraksi air lingzhi (ganoderma lucidum (curtis) p. karst)) pada tikus diabetes dengan induksi aloksan. J. Pharmascience. 2015; 2(1): 10-8.

13. Mise I, Vucic M. Comparison of syndecan-1 immunohistochemical expression in lobular and ductal breast carcinoma with nodal metastases. Anal. Cell. Pathol. (Amst). 2018; 2018: 9432375.

14. Carreón-Burciaga RG, González-González R, MolinaFrechero N, López-Verdín S, Pereira-Prado V, Bologna-Molina R. Differences in E-cadherin and syndecan-1 expression in different types of ameloblastomas. Anal. Cell. Pathol. 2018; 2018.

15. Setyawan B, Widiastuti MG, Rahmat M. Ekspresi syndecan-1, matriks metalloproteinase-2 dan il-1 $\alpha$ pada ameloblastoma multikistik (penelitian restrospektif analitik di rsup dr. sardjito tahun 2010-2014). J. Kedokt. Gigi. 2015; 7(2): 26-33.
16. Al-Otaibi O, Khounganian R, Anil S, Rajendran R. Syndecan-1 (CD 138) surface expression marks cell type and differentiation in ameloblastoma, keratocystic odontogenic tumor, and dentigerous cyst. J Oral Pathol Med. 2013; 42(2): 186-93

17. Brito-Mendoza L, Bologna-Molina R, IrigoyenCamacho ME, Martinez G, Sanchez-Romero C, Mosqueda-Taylor A. A comparison of Ki67, syndecan-1 (CD138), and molecular RANK, RANKL, and OPG triad expression in odontogenic keratocyts, unicystic ameloblastoma, and dentigerous cysts. Dis Markers. 2018; 2018: 7048531

18. Zong F, Fthenou E, Mundt F, Szatmári T, Kovalszky I, Szilák L, et al. Specific syndecan-1 domains regulate mesenchymal tumor cell adhesion, motility and migration. PLoS One. 2011; 6(6): 14816;

19. Peterfia B, Fule T, Baghy K, Szabadkai K, Fullar A, Dobos K, et al. Syndecan-1 enhances proliferation, migration and metastasis of HT-1080 cells in cooperation with syndecan-2. PLoS One. 2012; 7(6): e39474.

20. Lakkam B, Majage B, Astekar M, Gugwad RS, Giri G, Ramasahayam S. Immunohistochemical expression of syndecan-1 in oral dysplastic epithelium. J Cancer Res Ther. 2014; 10(1): 103-6.

21. Akl MR, Nagpal P, Ayoub NM, Prabhu SA, Gliksman M, Tai B, et al. Molecular and clinical profiles of syndecan-1 in solid and hematological cancer for prognosis and precision medicine. Oncotarget. 2015; 6(30): 28693-715.

22. Sayyad MR, Puchalapalli M, Vergara NG, Wangensteen SM, Moore M, Mu L, et al. Syndecan-1 facilitates breast cancer metastasis to the brain. Breast Cancer Res Treat. 2019; 178(1): 35-49.

23. Chute C, Yang X, Meyer K, Yang N, O'Neil K, Kasza $\mathrm{I}$, et al. Syndecan-1 induction in lung microenvironment supports the establishment of breast tumor metastases. Breast Cancer Res. 2018; 20(1): 66.

24. de Oliveira Barros EG, Palumbo A, Jr., Mello PL, de Mattos RM, da Silva JH, Pontes B, et al. The reciprocal interactions between astrocytes and prostate cancer cells represent an early event associated with brain metastasis. Clin Exp Metastasis. 2014;31(4):461-74 